\title{
FIRST REPORT OF THE MILLIPEDE Oxidus gracilis (DIPLOPODA, POLYDESMIDA, PARADOXOSOMATIDAE) IN SERBIA
}

\author{
Zvezdana S. Jovanović*, Dragan Ž. Antić, Vladimir T. Tomić* \\ Institute of Zoology, Faculty of Biology, University of Belgrade, \\ Studentski Trg 16, 11000 Belgrade, Republic of Serbia \\ *Corresponding author; E-mail: z.jovanovic.bio@gmail.com
}

(Received January 5, 2016)

\begin{abstract}
Ten specimens of Oxidus gracilis (C. L. Koch, 1847) were collected in the hothouse of Botanical Garden "Jevremovac" in Belgrade. This is the first finding of an alien millipede species in Serbia.
\end{abstract}

Key words: Serbia, hothouse, alien species, Oxidus gracilis.

\section{INTRODUCTION}

Presently, the Serbian millipede fauna comprises 103 species (ANTIĆ et al., 2013, 2014; ANTiĆ, 2015; JovANOVIĆ and ANTIĆ, 2015). The family Paradoxosomatidae belongs to the order Polydesmida, the second largest order of millipedes in Serbia with two families and 23 species (ANTIĆ et al., 2013). Oxidus gracilis (C. L. Koch, 1847) is the second representative of the family Paradoxosomatidae and the 104th millipede species in Serbia. To date, millipede species alien to Europe were not registered in Serbia (DAISIE, 2008), but considering that $O$. gracilis is a widespread successful anthropochore (STOEV, 2004), it is not surprising that the network of pathways among European greenhouses and hothouses travelled by this species eventually has come to include Serbia.

\section{MATERIALS AND METHODS}

Ten specimens of Oxidus gracilis were collected in the hothouse of Botanical Garden "Jevremovac" in Belgrade. Specimens were preserved in $70 \%$ ethanol and examined at the laboratories of Institute of Zoology, Faculty of Biology, University of Belgrade, using Carl Zeiss Jena Technival 2 binocular stereomicroscope. Gonopods were dissected and mounted in glycerin as temporary microscopic preparations and observed under a Carl Zeiss Axioscope 40 microscope. Picture of the living specimens was made with a Canon PowerShot SX530 HS digital camera. 


\section{RESULTS AND DISCUSSION}

Oxidus gracilis (C. L. Koch, 1947) (Fig. 1)

Fontaria gracilis C.L. Koch, 1847

Polydesmus gracilis: auctt.

Paradesmus gracilis: auctt.

Orthomorpha gracilis: auctt.

Orthomorpha (Kalorthomorpha) gracilis: auctt.

Material studied: Four adults ( 3 females and 1 male) and 6 juveniles were collected on 28 September 2015 by Dragan Antić in the hothouse of the Botanical Garden "Jevremovac" in Belgrade.

Details on biology of this well-known species have been given by SCHUBART (1934), CAUSEY (1943) and BlOWER (1985). It is the only millipede species alien to Europe with established populations in some natural ecosystems on the continent and in the Caucasus (STOEV et al., 2010). Its bisexual populations are maintained by laying eggs during the whole year (CAUSEY, 1943; BLOWER, 1985).
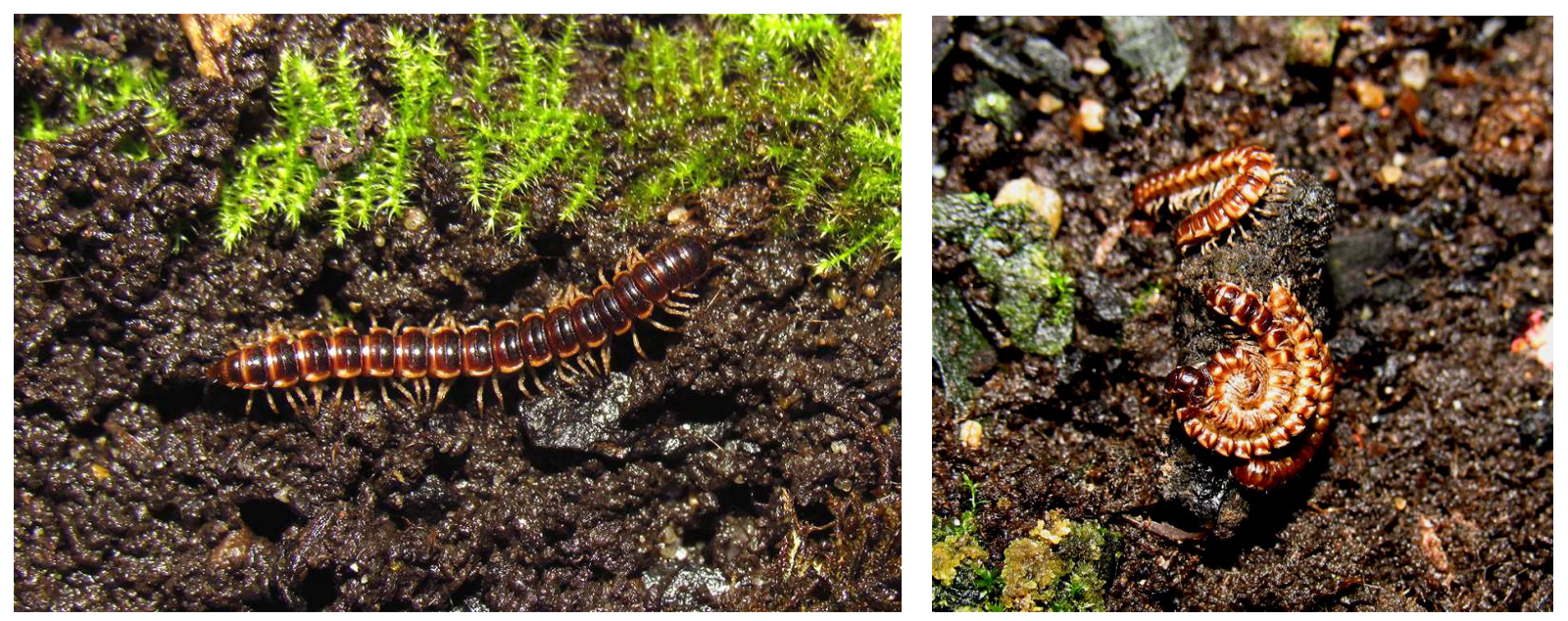

Figure 1. Oxidus gracilis (C. L. Koch, 1847) in the hothouse of the Botanical Garden "Jevremovac" in Belgrade (photo D. Antić).

Origin: The native range of the species is East or Southeast Asia (STOEV and KoRsós, 2010). COOK (1911) stated that the species originates from the East Indies. STOEV and KoRsós (2010) expressed the assumption about Ryukyu Islands of Japan as the possible site of origin of the genus, based on the finding of populations of the two congeners of $O$. gracilis in the natural forest habitats of these islands. Three out of four congeners of $O$. gracilis are distributed in Japan, but not only in the Ryukyu Islands (NGUYEN and SIERWALD, 2013). Japan, as a native territory of $O$. gracilis, was previously indicated by GOLOVATCH and KIME (2009), who noticed that the species favors higher altitudes in Middle America which could possibly reflect a northern temperate origin.

Habitat: $O$. gracilis has a high adaptive potential which enables it to populate various types of terrestrial natural habitats, agricultural, horticultural and artificial areas and those under varying human influence, as well as subterranean habitats (STOEV and KoRSÓs, 2010). Unable to survive longer than two hours under the temperature of $-4^{\circ} \mathrm{C}$, the species can only be found in the hothouses in the northern regions (STOEV and KoRSós, 2010).

Specimens from the hothouse of the Botanical Garden "Jevremovac" in Belgrade were found in shaded conditions under stones and branches, or walking and mating on a moist soil 
partially covered in moss (Figs 1 and 2). The species seems to have established a thriving population considering the observed reproductive behaviour and juveniles of different stadia. Temperature at the hothouse varies between $19-24^{\circ} \mathrm{C}$.
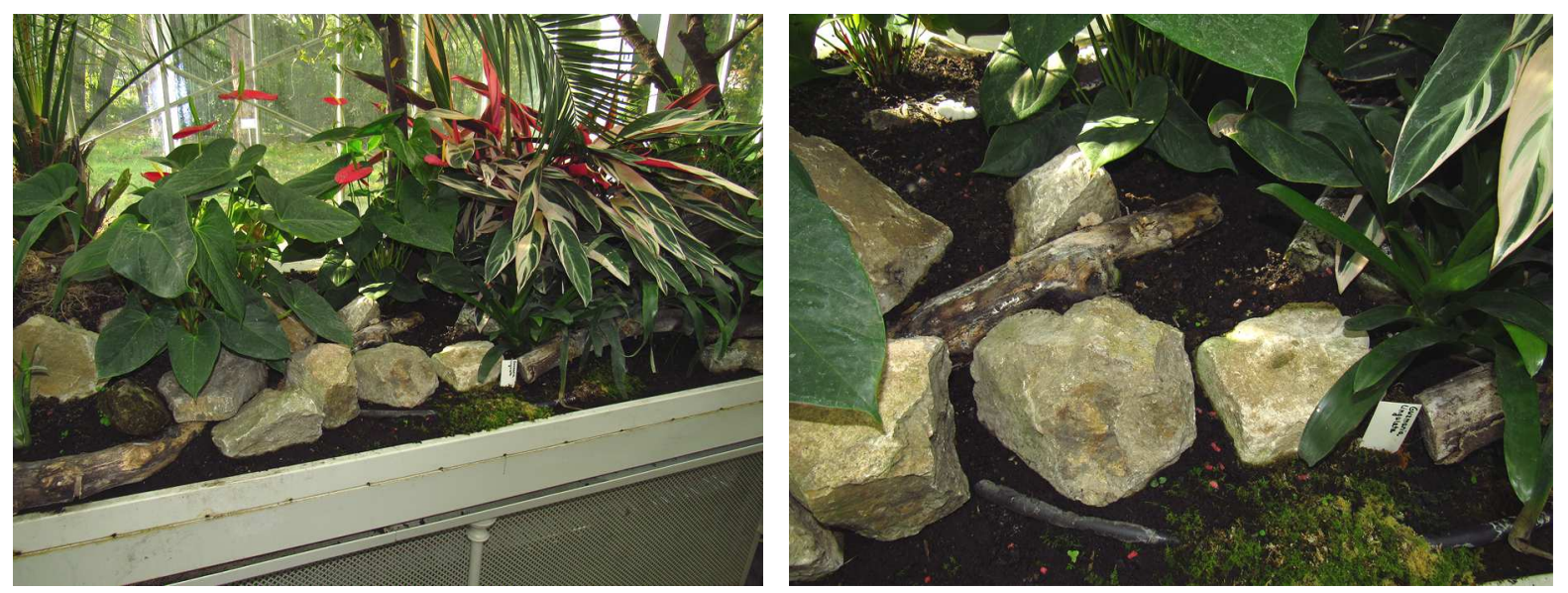

Figure 2. Habitat of Oxidus gracilis (C. L. Koch, 1847) in the hothouse of the Botanical Garden "Jevremovac" in Belgrade (photo D. Antić).

Distribution: Presumably, first finding of $O$. gracilis in Europe was on the Margaret Island in Danube, Budapest, reported by Tömösváry in 1879 (STOEV et al., 2010). SCHUBART (1934) stated that the species was brought to the Netherlands probably around 1880, and that its presence has been reported in 1882. STOEV et al. (2010) noted that Latzel (1884) gave first descriptions of $O$. gracilis from several cities in the Netherlands. The millipede expanded its Asian range through tropical plants trade pathways that connect greenhouses and hothouses of cities across the world. It is possible that it has been introduced from Europe to the other parts of the world. SHELLEY et al. (1998) proposed that it "may be the world's most common nonparasitic metazoan animal".

The species is present in many parts of the world under favourable climatic conditions and in 33 European countries (STOEV and Korsós, 2010; STOEV et al., 2010).

This is the first record of a myriapod from a hothouse/greenhouse in Serbia. Controlled temperature and humidity, as well as the variety of plant species have probably created a proper environment for some other alien myriapod species, which could be a suitable subject for more comprehensive study.

\section{Acknowledgments}

This work was supported by the Serbian Ministry of Education, Science, and Technology (Grant 173038). The authors would like to thank two anonymous reviewers for their constructive comments.

\section{References:}

[1] Antić, D.Ž., Ćurčıć, B.P.M., Tomić, V.T., ĆurČić, S.B., Stojanović, D.Z., Dudić, B.D., MaKarov, S.E. (2013): One hundred millipede species in Serbia (Arthropoda: Myriapoda: Diplopoda). Archives of Biological Sciences, Belgrade 65 (4): 1559-1578.

[2] Antić, D.Ž., Tomić, V.T., ĆurČIĆ, B.P.M., ĆurČIĆ, S.B., STAMEnKoviĆ, S.P., Lučić, L.R., MaKarov, S.E. (2014): Genus Belbogosoma Ćurčić and Makarov, 2008, with 
descriptions of new troglobitic species from east Serbia, Balkan Peninsula (Diplopoda: Chordeumatida: Anthroleucosomatidae). Archives of Biological Sciences, Belgrade 66 (2): 907-918.

[3] ANTiĆ, D.Ž. (2015). Endemična pećinska fauna diplopoda (Myriapoda, Diplopoda) na teritoriji Srbije. 8. Simpozijum o zaštiti karsta. Plenarni referati i rezimei, Pirot, 30.1001.11.2015: 25.

[4] Blower, J.G. (1985): Millipedes. - In: KermaK, D.M., BARnes, R.S.K. (eds): Synopses of the British Fauna (New Series) 35. E. J. Brill/Dr. W. Backhuys, London, 242 pp.

[5] Causey, N.B. (1943): Studies of the life history and the ecology of the hothouse millipede, Orthomorpha gracilis (C.L. Koch 1847). American Midland Naturalist 29: 670-682.

[6] CooK, O.F. (1911): The hothouse millipede as a new genus. Proceedings of the United States National Museum 40 (1842): 625-631.

[7] DAISIE European Invasive Alien Species Gateway (2008): Serbia. Available from: http://www.europe-aliens.org/regionFactsheet.do?regionId=YUG-SE;M00 [Accessed $15^{\text {th }}$ October 2015].

[8] Enghoff, H., KImE, R.D. (ed.): (2013): Fauna Europaea. Myriapoda. Fauna Europaea, version 2.6.2, available from http://www.faunaeur.org.

[9] Golovatch, S.I., KIME, R.D. (2009): Millipede (Diplopoda) distributions: A review. Soil Organisms 81 (3): 565-597.

[10] Jovanović, Z.S., ANTIĆ, D.Ž. (2015): First record of Cylindroiulus horvathi (Diplopoda, Julida, Julidae) in Serbia. Kragujevac Journal of Science, Kragujevac 37: 143-148.

[11] Nguyen, A.D., Sierwald, P. (2013): A worldwide catalog of the family Paradoxosomatidae Daday, 1889 (Diplopoda: Polydesmida). Check List 9 (6): 1132-1353.

[12] Schubart, O. (1934): Tausendfüßler oder Myriapoda. I: Diplopoda. Die Tierwelt Deutschlands und der angrenzenden Meeresteile 28: 1-318.

[13] Shelley, R.M., BAuER, S.B., SWIFT, S.F. (1998): The millipede family Paradoxosomatidae in the Hawaiian Islands (Diplopoda: Polydesmida). Bishop Museum Occasional Papers 56: 43-53.

[14] Stoev, P. (2004): Myriapoda (Chilopoda, Diplopoda) in Urban Environments in the City of Sofia. In: Penev, L., Niemelë, J., Kotze, D.J., ChIPEV. N. (eds). Ecology of the City of Sofia. Species and communities in an Urban Environment, Sofia-Moscow: Pensoft Publishers: 299-306.

[15] Stoev, P., Korsós Z. (2010): 14.2. - Oxidus gracilis (C.L. Koch, 1847) (Diplopoda, Polydesmida, Paradoxosomatidae). In: Roques, A., Kenis, M., LeES, D., LoPeZVAAMONDE, C., RABITSCH, W., RASPlus, J.-Y., RoY, B.D. (eds). Arthropod invasions in Europe. BioRisk, 4 (2), Pensoft, 500 pp.

[16] Stoev, P., Zapparoli, M., Golovatch, S.I., Enghoff, H., AkKari, N., Barber, A. (2010): Myriapods (Myriapoda). Chapter 7.2. In: Roques, A., Kenis, M., Lees, D., Lopez-Vaamonde, C., Rabitsch, W., Rasplus, J.-Y., and Roy, B.D. (eds). Allien terrestrial arthropods of Europe. BioRisk, 4 (1): 1028 pp. 